\title{
Customer Base Strategies
}

\author{
${ }^{1}$ Agwamba Adolphus Chibuzor Ph.D, ${ }^{2}$ Onwudiwe Uju Jovita Ph.D, ${ }^{3}$ Ugwuegbu Charles Onyemachi \\ M.sc, ${ }^{4}$ Opara Darlington Osondu M.sc
}

\author{
1, 2, 3,4 Discipline: Business Management Imo State University Nigeria
}

\begin{abstract}
:
Growing and sustaining the customer base of an organization is always a challenge to firms' operating in an intense and competitive industry and where the cost of brand switching is relatively low. For an organization to adopt any strategy, the need to scan its environment will be necessary to avoid making a strategic mistakes that are capable of causing an organization its life as a corporate entity. The study aimed at identifying and discussing strategies an organization can adopt in growing and sustaining its market share in a given industry. These strategies include; innovation strategy, market segmentation strategy, market expansion strategy, 80/20 business strategy, and customer relationship retention strategies. A research model was formulated for the purpose of guiding further studies.
\end{abstract}

\section{Introduction}

Customers are indeed an asset to the firms. A good customer base ensures a continuous source of future revenue due to repeat purchases done by them and cross-buying of other products offered by the organization (Dawes, 2009). If a firm is incurring costs to attract new customers, then it is advisable for such firm(s) to maintain their existing customer base rather than losing and replenishing the lost customers.

A customer base is the group of customers who repeatedly purchase the goods or services offered by a company. These customers are source of investment for such company.

The customer base of a firm can further be defined as a process of servicing a company's target market through research and development, understanding of customers' behavior, and offering products/services that will lead to repeat purchase.

Customer base strategies can be seen as a strategic move by a firm to grow, and sustain its competitive position. Customer base strategies can further be defined as a set of plans intended to achieve a large number of customers for the purpose of increasing the purchase of a firm's goods and services. These strategies enables an organization to make earn above industrial average. An example of customer base strategy is the acquisition of Mimee Noodles and Dangote Noodles by De-United Foods Industries Limited (DUFIL) makers of Indomie Noodles to increase their customer base. Another example is the Value Innovation strategy adopted by Multichoice in 2011. By developing an Application called the GOTV \& DSTV mobile, their esteemed customers' from all market segments were able to enjoy the very home of television.

In a time of dynamic changes in the environment of companies generated by the intensification of competition and globalization of markets, the growing possibility of satisfying needs through goods, services, ideas, rights and various combinations of these, companies concentrate more and more on the customer (Sunil \& Lehman, 2009).

To attract and keep customers, and thus make returns, firms' must be novel in finding new and better ways of creating value and differentiating their market offerings. While to maximize the market scale, companies need not only focus on the customers but also need to focus on non-customers. Kim and Mauborgne (2005) recommend that a company should consider the non-customers before customers, common points before different, and the merger market segments before the multi-level market segments. And they should separate the non-customer into three tiers: "Soon-to-be" noncustomers who are on the edge of the company's market, waiting to jump ship; "Refusing" noncustomers who consciously choose against the company's market; and "Unexplored" noncustomers who are in markets distant from the company (Kim and Mauborgne, 2005). 
The issue of acquiring and retaining customers has been a strategic issue, especially in an industry that competition is highly tensed. Using the Telecommunication industry for example, strategic players in that industry are having "leaky bucket" probably because of the competitive nature of the industry. Below is an analysis of drop in market shares of these major players:

Market Share of GSM Operator (Active Subscribers) as at 2014

\begin{tabular}{|c|c|c|c|}
\hline MTN & GLO & AIRTEL & EMTS:9MOBILE \\
\hline $59,893,093$ & $28,219,089$ & $27,556,544$ & $21,103,794$ \\
\hline $44 \%$ & $21 \%$ & $20 \%$ & $15 \%$ \\
\hline
\end{tabular}

Source: Nigeria Communication Commission, 2014

Market Share of GSM Operator (Active Subscribers) as at 2017

\begin{tabular}{|c|c|c|c|}
\hline MTN & GLO & AIRTEL & EMTS:9MOBILE \\
\hline $36,069,597$ & $26,99,817$ & $23,985,203$ & $11,338,839$ \\
\hline $36.5 \%$ & $27.4 \%$ & $24.3 \%$ & $11.5 \%$ \\
\hline
\end{tabular}

Source: Nigeria Communication Commission, 2014

From the above table, MTN in three years lost 23,823,496 active subscribers resulting in $8 \%$ loss in market share, Glo lost 25,519,272 active subscribers with a 6\% increase in market share, Airtel loss 3,571,341active subscribers with a $4 \%$ increase in market share while 9 Mobile loss 9,764,955 active subscribers with a $4 \%$ decrease in market share.

The above analysis shows that growing and retaining customers is actual a challenging issue faced by firms operating in any given industry.

\subsection{Statement Problem}

Whenever a firm's products or services is in constant use in chasing and beating the competition in a particular sector, the firm's market share will start dropping once a high-value product is being launched in that industry by other competitors. A typical example is a drop in market share of most table water company in Owerri, Imo State as a result of new table water called 'Mangero' because of its beautiful design. The product as at now should be among the bestselling table waters within Owerri. The simple reason for this strategic over-take is that the firms' operating in this industry doesn't innovate and as such, a single product has been in constant use in chasing and beating the competition.

Furthermore, other challenges that have the potential of affecting the customer base of a firm is that the majority of firms are busy competing for share in a shirking market. Thus, for a firm to grow and retain its customer base in this competitive era, such a firm must adopt some sound strategies.

\subsection{Purpose of the Study}

The very aim of this study is to discuss customer base strategies. This research discussed strategies a firm can adopt in improving, and sustaining its customer base. They include; value innovation strategy, segmentation strategy, market expansion strategy, 80/20 business strategy, and relationship retention strategies.

\subsection{Customer Base Strategies}

The choice of strategy an organization will adopt in growing and sustaining its customer base is based on environmental factors peculiar in that industry. Hence, the need to appraise the environment before accepting any strategy will be very essential. These factors include regulatory, political, economic, socialcultural, technological and competitors. These environmental factors have the ability of influencing the strategic choice of any organization regarding of increasing its customer base. An example is a regulatory force which shapes the type of promotional strategy an organization must adopt and the kind of goods/service an organization is expected to manufacture or render to the public.

An example of how government regulations affect companies' strategy is the case of network providers in Nigeria. According to Aginam (2013), the Nigerian Communications Commission (NCC) on February 28, 2013 slammed a total of N22 million fines on the four GSM operators including MTN, Globacom Limited, Emerging Markets Telecommunications Services Ltd (Etisalat) and Airtel for contravening the ban on promotions and lotteries on their respective networks, of the telecoms regulatory agency. It would be recalled that the Nigeria Communications Commission (NCC) had earlier in a letter dated November 8 , 
2012, directed all the licensees to discontinue all promotions and lotteries running on their networks with immediate effect Aginam (2013).

The ban covered proposed and approved promotions and lotteries after the Commission received several complaints from consumers and stakeholders against various promotions among the network providers in Nigeria. Accordingly, MTN Nigeria Communications Ltd was fined N10,000,000 (Ten Million Naira) on account of five promotions at N2,000,000(Two Million Naira) for each advert while Etisalat was to pay N6,000,000 (Six Million Naira) for three promotions in its network. Similarly, Airtel was fined N4,000,000 (Four Million Naira) for running two promotions against the ban while Globacom was fined N2,000,000 ( Two Million) for one advert (Aginam, 2013).

Meanwhile, sanctions on MTN were as a result of five promotions including, Free Airtime for MTN to MTN calls (8 AM - 5 PM), MTN to MTN SMS and free MB for Data. Dial *559\#, Free N100.00 airtime for MTN to MTN calls, Airtime Bonus valid for life. Dial *559\#, MTN Super Saver, get 500\%, bonus valid till midnight. Dial *507\# and Recharge with N100.00 today and get N500 FREE credit instantly. Hurry and recharge before January 22nd. For Etisalat, three promotions that attracted penalties include 'buy a MIFI device and get 1GB free for six months', purchase a router device and get $50 \mathrm{MB}$ free data spread over four months and get 30\% instant bonus on every plan subscription/renewal over 200MB. On the other hand, Airtel Nigeria was penalized for running two promotions which are; dongle and MIFI offerings and reverse auction service. Also, Globacom has been sanctioned for engaging in one promotion of BUY Samsung Galaxy SIII, or Galaxy Note II and get free $500 \mathrm{MB}$ on activation, and free 100MB X 6 Months (Aginam, 2013).

Hence, the need for a firm to appraise its environment before adopting any strategy will be needful and can be a source of competitive advantage.

\subsubsection{Value Innovation Strategy}

We are in a century where firms' who wishes to excel in their respective industries must begin to have customer mindset. This customer mindset will enable them to adopt appropriate strategies for increasing their customer base. The core concept of the customer base strategies should be the exchange or creation of economic value between the company and its customers'. Value must begin with the customer and goes back to the company; the company allocates resource based on the potential value of the customer. That means that companies have to change their product-focused 'inside-out' thinking, to customer-focused 'outside-in' thinking Kirkly (2016). The bases of every customer base strategies should be to grow, engage, and retain the company's customers'.

Exploiting core competencies and attaining synergy (the interaction of organization's units to produce a joint effect) will help a company creating value for their customers'. In this context, a value is seen as the combination of benefits received and cost paid by the customer. A product that is low in cost but does not provide benefits to customers' is not a good value. For example, an Airline company that splashes down prices, but experiences delay in takeoffs will lose customers. Delivery value to the customer should be at the heart of a firm's strategy. In adopting this strategy in growing and sustaining the customer base of a firm, managers must understand which part of company's operation (product lines, \& services) creates value and which do not, for a company can only be profitable only if the value it provides is higher than the cost of the resource. When a firm fails to accurately appraise its value creating potentials, it becomes uncritically satisfied with its achievements.

Kim and Mauborgne (2005) the advocators of Blue Ocean Strategy believes that "Value innovation can be initiated in the region where a company's actions favorably affect both its cost structure and its value proposition to customers. Cost savings by an organization can be achieved by eliminating and reducing the factors an industry competes on. Customer value can be raised by increasing and creating elements the industry has never offered. Over time, costs are reduced further as scale economies kick in due to the high sales volumes that superior value generates (Kim and Mauborgne, 2005). 




Value Innovation framework by Kim and Mauborgne (2005)

Using the value innovation strategy to engage, grow and sustain the customer base of a company is found on the assumption that once a firm can achieve cost leadership in its industry (when a company can produce at lower cost than competitors and still offer quality and earn a reasonable profit), such a firm will be strategically positioned to succeed in a price war while still making returns.

Achieving cost leadership means a lot to a firm because their customer base will be preserved when such sensitive customer cannot find lower prices of such product elsewhere. Again if substitute products or potential new entrants occur, the lower-cost producer is better positioned than the high-cost rivals to prevent loss of market share. Hence, the low price acts as a barrier against new entrants and substitute products. In essence, value innovation encourages firms' to pursue cost leadership and differentiation strategies as the best means of maintaining their market shares.

Another aspect of value innovation strategy when aligned with the company's strategy for growing and sustaining customer base, is that such a firm must not allow its competitors to set parameters of their strategic thinking. For a firm to seek growth through retaining and expanding its customer base, such a firm must create new value for customers through product innovations.

Creation of new value for customer through product innovation was used by Guiness Nigeria Plc when the company noticed that its customer base for MaltaGuiness (one of its products line in the soft drink industry) has started depreciating drastically, in order to sustain its presence in the soft drink industry, the company made a strategic move to acquire new customers and retain existing loyal customers. This strategic move gave birth to a new product 'Dubic Malt' in 2017. By creating new value for customers through product innovation, Guiness Nigeria Plc was able to expand and sustain its market-share in the non-alcoholic sector. Another company that created new value for customers through product innovation is Multichoice owners of DSTV. The firm launched GOTV and DSTV mobile in 2011, enabling customers from all market segments to enjoy the very home of television experience. Through this strategic move (creation of new value for the customer), the company became the market leader in the Multichannel \& Multiplatform Digital Television operator in Africa covering over 50 countries while its rival Startimes though new in Nigeria is still struggling to gain a substantial share in the market. The above scenario explains the power of value innovation strategy in growing and retaining the customer base/share of a company.

\subsubsection{Market Segmentation Strategy}

Market segmentation has been an old marketing strategy in growing customer base of a firm. Kotler et al. cited in Anyanwu (2013) sees market segmentation as the process of dividing a market into a distinct group of customers' who have various needs, attributes, or behavior who might require separate products or marketing programs. In adopting this strategy, a firm may segment its product/service offerings base on 
geographical location (geographical segmentation), demographic nature of customers like sex, age, etc. (demographic segmentation), social-economic segmentation like education, income, status, etc.

Market Segmentation strategy can be seen in action among commercial banks offering different packages for their customers in a bid to capture all segments of the market like students account, savings account, current account, fixed deposit account, joint account, etc. This strategy (market segmentation) has indeed helped them to expand and sustain their market shares.

Companies operating in the food industry like Power oil, Kings oil, Peak milk, Cowbell milk, Loyal milk, and others have all adopted this strategy in capturing and satisfying the needs of different market segments by considering their demographic and social-economic differences. As at last 2017, the price for $150 \mathrm{ML}$ Power Oil and Kings Oil sachets were sold for N100. Early 2018, Kings Oil and Power Oil went further and segmented their products, now; they have 75ML that is sold at N50. Peak milk, Cowbell milk and Royal milk also have the smallest size of their products 'in sachets' selling at N50 and N60 respectively.

\subsubsection{Market Expansion Strategy}

Customer base (market share) of an organization can also be increased and sustained via diversifying its markets and product categories. An organization can grow its customer base either by using an existing product in a new market or by developing a new market and a new product. Whichever way, the essence of this strategy is to enable a firm to maintain a lead in its industry.

Strategies like Merger and Acquisitions (M\&A), Joint Venture, Strategic Alliance, etc. are often seen in use by firms in growing their customer base and maintaining their strategic positions in their respective industries.

For example, in the food industry specifically, the Noodles industry, De-United Foods Industries Limited (DUFIL) makers of Indomie Noodles were able to adopt this strategy (market expansion through acquisition) to maintain their lead as the industry leader. Despite the influx of new entrants in the industry such as Tummy Tummy, Golden Penny noodles, Honeywell noodles, Dangote noodles, Mimee noodles, Chef me Engle Food, etc. Indomie expanded its customer base by acquiring Mimee noodles (a subsidiary of May \& Baker) for N775M last year November 2017. The companies went further and acquired Dangote noodles for N3.35B the same 2017 (Oluseyi, 2017). To protect its market base, Indomie always embarks on promotional activities. A periodic promotion such as the scratch and win promo, visiting of schools both primary and secondary to prepare Indomie for the children, visiting and partnering with amusement parks or fun centers during children's day celebration as witnessed in this year 2018 last children's day celebration at Rosallas Fun Center, Igando, Lagos.

\subsubsection{The 80/20 Business Strategy}

In the world of business, not all customers and products are profitable. A firm must be able to identify which particular market segment or product is more attractive to channel their marketing efforts in servicing those customers well or improving on those products line. Pareto 80-20 rule is applicable when a firm tries to recoup its investment it has made in a particular market.

The principle of $80 / 20$ can be seen as a strategic option which can be used to analyze and identify strategic customers' of a business to strengthen such relationship. 80/20 strategy can also be used by companies to increase their profitability by channeling resources on $20 \%$ products that account for $80 \%$ sales and $20 \%$ customers' that gives the company $80 \%$ profit.

In the world of business, 80-20 business strategy refers to the distribution ratio between profits on the one hand and products/customers on the other hand: for instance, $80 \%$ of an organization's profits may be attributed to $20 \%$ of its products and $80 \%$ of a company's sales may come from $20 \%$ of the organization's customers'. A structured application of "Pareto 80-20" analytics will allow businesses to hone in on the most profitable activities with a laser-sharp focus. The highest advantage, however of the Pareto 80-20 is in guiding business strategy. Once the management of a business organization must have understood the analysis and the practicable methods behind the Pareto 80-20 process, such an organization should be capable of achieving the following objectives:

1. Develop a reliable classification of customers by their profitability

2. Develop a reliable ranking of products by their profitability 
In applying the Pareto's principle growing a firm customer base, one may find out that some customers are vital. Most are not. Some sales efforts are wonderfully productive. Most are inefficient. Some will lose you money. This principle suggests that a firm should channel its marketing and sales effort where they absolute advantage (customer group, functions and related technology) by offering something that is different in terms of price and value to its potential customers than competitors. By being unique and providing such value, such a firm can make higher profits in the process. Must profitable organizations draws their success story from this uncomplicated principle. The principle is summarized thus:

- $80 \%$ of organizational profits are from $20 \%$ of customers

- $80 \%$ of product sales from $20 \%$ of products

- $80 \%$ of sales from $20 \%$ of advertising

- $80 \%$ of customer complaints from $20 \%$ of customers

- $80 \%$ of sales from $20 \%$ of the sales team

The above entails that the business should (Koch, 2004,):

a) Focus every salesperson's efforts on the 20 percent of products that generate 80 percent of sales. Make sure that the most profitable products attract four times the credit that an equivalent Nair of less profitable products does. The sales force should be rewarded for selling the most profitable products, not the least profitable.

b) Focus every salesperson's efforts on the 20 per cent of customers who generate 80 percent of sales and 80 per cent of profits. The firm should be able to teach the sales force to rank their customers by sales and profits. Insist that they spend 80 percent of their time on the best 20 percent of customers, even if they have to neglect some of the less important customers. Spending more time with the minority of high-volume customers' should result in higher sales to them. If opportunities to sell more existing products have been exhausted, the sales force should concentrate on providing superior service, so that existing business will be protected, and on identifying new products that the core customers want.

c) Finally, get the sales force to revisit old customers who have provided good business in the past that is, knocking on old doors or calling old phone numbers.

\subsubsection{Customer Relationship Retention Strategies}

The dynamism of today's competitive business environment have forced firms that wants to beat competition to see reasons why in creating a new market space called the 'Blue Ocean' is sacrosanct. By ignoring competition in the Red Ocean market, such a firm will be strategically positioned in acquiring new customers'. For instance, the introduction of Zero Coca by Coca-Cola for Diabetic patients in Nigeria, has enabled Coca-Cola in acquiring more market share than Pepsi. However, one can say that most firms' have "leaky bucket" due to the fact the annual defection rate is higher than the acquisition rate. The study of Sunil \& Lehman (2009) reported that the average retention rate for U.S. companies is about 80 . The above report of Sunil \& Lehman (2009) means that the average company loses the equivalent of its entire customer base in about five years.

Studies also show that the price of acquisition is generally much higher than the cost of retaining existing customers. Therefore, it seems obvious that a firm should focus on keeping its existing customers. Unfortunately, many companies don't even know their customer retention or defection rates. Part of this problem lies in the lack of appreciation for the importance of customer retention (Sunil \& Lehman, 2009).

In a nationwide customer retention survey, majority of the respondents reported that $75 \%$ of the sales were from existing customers (Carter, 2008). The intensification of competition can be said to have necessitated the adoption customer retention strategies among firms.

Customer retention is "customer's intention to stay loyal with the service provider especially in the context of switching costs" (Edward and Sahadev, 2011). Customer retention is the inclination of the customers to stay with the service provider in the future (Ranaweera and Prabhu, 2003). Similarly, Stauss (2001) sees customer retention as "customer's liking, identification, commitment, trust, willingness to recommend and repurchase intentions with the first four being emotional-cognitive retention constructs and the last two being behavioral intentions".

Some positive customer relationship retention strategies include: 
1. Financial bonds: these are strategies that are built around financial rewards. There are three variants-volume and frequency rewards, building and cross-selling, and stable pricing. Volume and frequency rewards are designed to retain consumers that buy in large quantities and frequently too. For example, Nigeria companies are often seen using this strategy in which customers that have maintained a long relationship with the firm are rewarded. Building and cross-selling involves linking the firm's incentive with rewards available in other firms. Some promotional activities are designed in such a way that loyal customers' are provided with opportunities to visit centers of attraction or international events like World Cup tournament at the company's expense. Stable pricing is a kind of incentives whereby loyal customers' are given the privilege of buying at a given price over a long period of time even if prices have been adjusted upwards for other buyers.

2. Social bonds: Social bond is the creation of long-term relationships with the customers through social networks and individuals. In this respect, companies consider the customers as different individuals and try to meet the needs of various customer groups by means of custom services. Social bond enables companies to enjoy more competitive advantages when compared with financial bond which centers on price incentives. God and Senhuta (2000) pointed out that when there are close interactions between business partners, they are more likely to be depended on each other and they can affect satisfaction, commitment, and trust of that part. Wilson and Momalaneni cited in Mohammad et al. (2015) showed that commitment of relationship retention will be stronger when stronger individual relationships and social links exist between the members within a business relationship.

3. Customization Bonds: Intimate knowledge of customers and their needs developed through a learning relationship is very beneficial in retaining valuable customers. Customer closeness implies that a consumer is diligently sharing information during interactions and contributing in the marketer's endeavor to customize the products, services or any aspect of the marketing mix. Every member of the organization uses every opportunity of interaction to learn new things about the customer and add to the organizational knowledge of the customer.

4. Structural bond: When companies provide more custom services and emphasize high-quality services/products and long-term relationships including trust, satisfaction, and commitment, structural bond is said to have been established. For instance, companies like Coca-Cola, Pepsi, Hero Beer etc. provides customized refrigerators, chairs, tables etc. to their retailers. With such integrated services provided through structural bond, firms' can easily satisfy their customers' demands. Han et al. cited in Mohammad et al (2015) demonstrated that by the dominance of complex purchase conditions, the companies with stronger structural relationships could offer multiple custom services with the added value. They can achieve more trust, satisfaction, and commitment while keeping long-term relationships with the customers as compared to those with weak intimacy. Furthermore, Lin et al. (2003) and Rodriguez and Wilson (2002) confirmed that structural relationships have positive impacts on trust, satisfaction and commitment which are regarded as the bases for keeping customers' (Yu and Tang, 2013). Structural bonds can be said to be the strongest bonds and the most difficult to break. In order of significant, structural bonds are stronger than customization bonds; while customization bonds are stronger than social and financial bonds. As the closeness become stronger, customers' loyalty grows, and the opportunities for reaping the dividend of relationship marketing increases.

From the above strategies discussed, an organization can retain its existing customer by offering some financial incentives-lower prices for volumes or for customers who have been patronizing the firm over a period of time. An organization can retain its customers' when it finds ways to offer solutions to their changing needs.

\subsection{Empirical Review}

Customer base strategies is yet to draw much attention from researchers. However, the relevance of the research is supported by the study of Gengeswari, Padmashantini, \& Sharmeela-Banu, (2013) on Impact of Customer Retention Practices on Firm Performance. They argued that customer retention has become the buzzword among both practitioners and academics due to its significant impact towards the improvement in firm performance. Hierarchical regression analysis was employed to examine the impact of customer 
retention towards firm performance alongside with the demographic profiles as the moderator. Four dimensions of customer retention namely word-of-mouth, price insensitivity, repeat purchase and noncomplaining behavior as well as demographic profiles were found to have significantly influenced firm's performance (customer satisfaction).

Fig 2: Conceptual Model for the Study

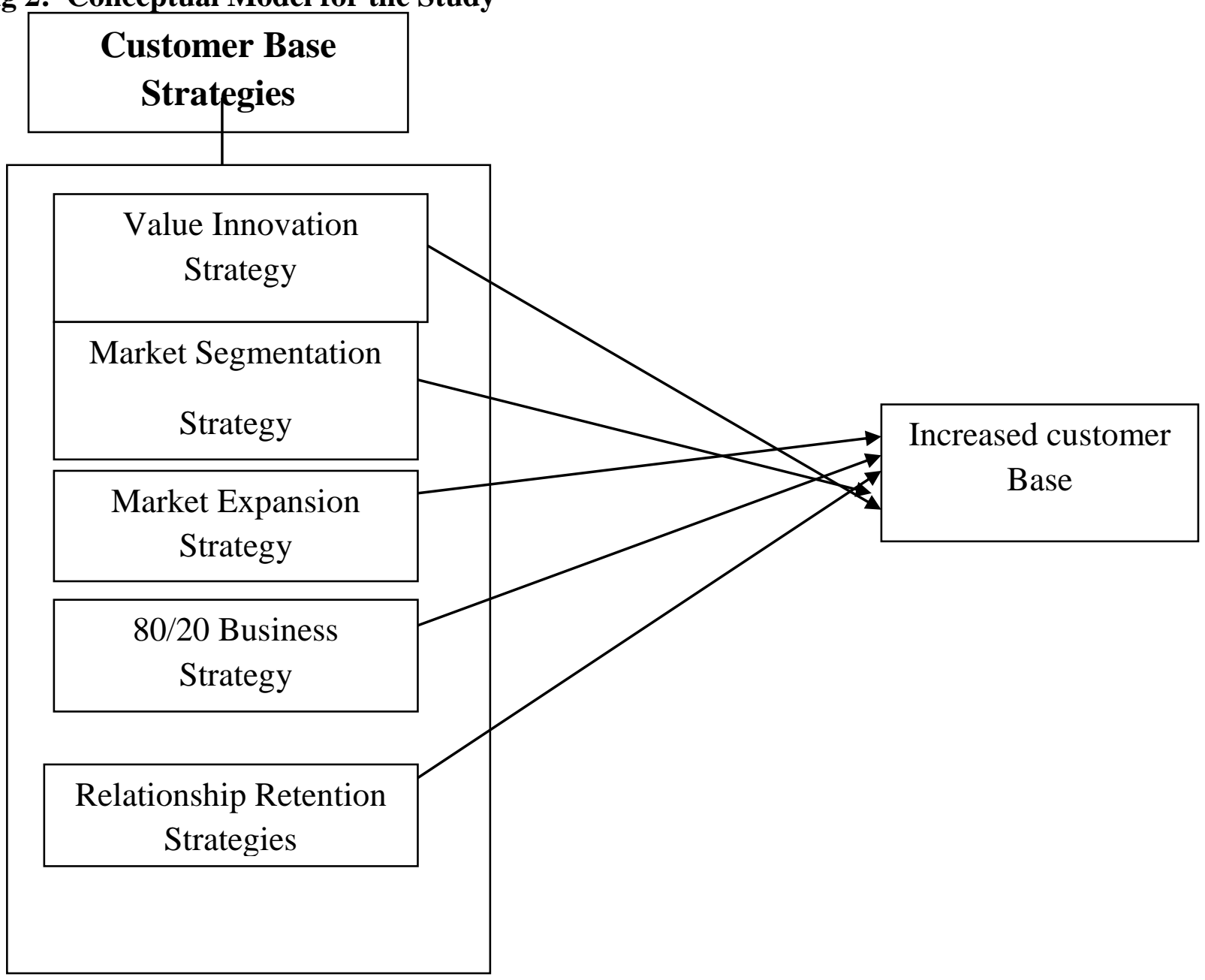

\section{Conclusion}

Achieving a sustained competitive advantage (SCA) in this $21^{\text {st }}$ century reside on having a customer mindset. This study has demonstrated that effective customer-based strategies should take into consideration value innovation strategy, market segmentation strategy, market expansion strategy, 80/20 business strategy, and relationship retention strategies. With these strategies, a firm can grow, and sustain its customer base at a profit. The study also proposed a customer base strategy model that will guild further research. The model assumed that through value innovation (cost leadership and product development) a firm's customer base will improve directly. Secondly, market segmentation strategy, market expansion strategy, 80/20 business strategy, and relationship retention strategy will enhance customer satisfaction thereby resulting to an increased market share of the firm. Also, channeling marketing efforts to $20 \%$ customers and products that gives a firm $80 \%$ profit will enhance organizational returns.

Conclusively, effective customer base strategies should take into cognizance the two sides of customer value which are; the value the firm provides to the customer in terms product/service assortment and brand, and the value the customers' provides to the company in terms of profit. Conclusively, effective implementation of customer base strategies and its periodic review and appraise grow and sustain the profit and assets base of the organization.

\section{References}

[1] Bendapudi, N. and Leone, R.P. (2003). Psychological implications of customer participation on co-production. Journal of Marketing, (67), 14-28. Industrial Marketing Management, 42(4), 544551. 
[2] Carter (2008). Customer perceived value: a substitute for satisfaction in business

markets.

Journal of Business and Industrial Marketing. 17(2/3): 107-18.

[3] Dawes, F. (2009). Customer Relationship Management: Concepts and Tools. Elsevier: Oxford.

[4] Emeka Aginam (2013). Nigeria NCC sanctions mobile operators with N22m fine. www.Vanguardngr.com

[5] Gengeswari, K; Padmashantini, P., \& Sharmeela-Banu, S.A. (2013). Impact of Customer Retention Practices on Firm Performance. International Journal of Academic Research in Business and Social Sciences July 2013, Vol. 3, No. 7 ISSN: 2222-6990

[6] Edward H. \& Sahadr (2011). Measuring switching costs and the determinants of customer retention in internet-enabled businesses: a study of the online brokerage industry. Information Systems Research, 13 (3): 255-274.

[7] Johnston, R. and Clark, G (2001). Service operations management. London: Prentice Hall.

[8] Jennifer Kirkby (2016): Developing a Customer Strategy.

[9] Newman, MEJ. (2011) "Power laws, Pareto Distributions, and Zipf's law" (PDF).p.11. Retrieved 10 April.

[10] Mohammad Jafar Tarokh and Abbas Sheykhan (2015). Recognizing Relationship Marketing Dimensions and Effects on Customer Satisfaction, Loyalty and Word of Mouth Advertisement. MAGNT Research Report (ISSN. 1444-8939) Vol.3 (4). PP: 62-86

[11] Kim,C.W. and R. Mauborgne. (2005). "Blue Ocean Strategy: How to Create Uncontested Market Space and Make the Competition Irrelevant". Harvard Business School Press, Boston, MA.

[12] Koch, Richard (2000). The 80/20 Principle : the Secret of Achieving More with Less. New York: Doubleday. ISBN 1-87784-351-4

[13] Sunil Gupta \& Donald Lehman (2009). Managing Customer as Investments: Strategic Value of Customers in Long run.

[14] Statuss, H. (2001). The importance of customer satisfaction in relation to customer loyalty and retention. UCTI Working Paper. Asia Pacific University College of Technology and Innovation, Malaysia.

[15] Shaw, C. and Ivens, J. (2002). Building Great Customer experiences. London: Palgrave. 